\title{
Review Article \\ Phosphate and Cardiovascular Disease beyond Chronic Kidney Disease and Vascular Calcification
}

\author{
Sinee Disthabanchong \\ Division of Nephrology, Department of Medicine, Faculty of Medicine, Ramathibodi Hospital, Mahidol University, Bangkok, Thailand
}

Correspondence should be addressed to Sinee Disthabanchong; sineemd@hotmail.com

Received 14 February 2018; Accepted 6 March 2018; Published 8 April 2018

Academic Editor: Nicolas Verheyen

Copyright (C) 2018 Sinee Disthabanchong. This is an open access article distributed under the Creative Commons Attribution License, which permits unrestricted use, distribution, and reproduction in any medium, provided the original work is properly cited.

\begin{abstract}
Phosphate is essential for life but its accumulation can be detrimental. In end-stage renal disease, widespread vascular calcification occurs as a result of chronic phosphate load. The accumulation of phosphate is likely to occur long before the rise in serum phosphate above the normal range since several observational studies in both general population and early-stage CKD patients have identified the relationship between high-normal serum phosphate and adverse cardiovascular outcomes. Consumption of food high in phosphate increases both fasting and postprandial serum phosphate and habitual intake of high phosphate diet is associated with aging, cardiac hypertrophy, endothelial dysfunction, and subclinical atherosclerosis. The decline in renal function and dietary phosphate load can increase circulating fibroblast growth factor-23 (FGF-23) which may have a direct impact on cardiomyocytes. Increased FGF-23 levels in both CKD and general populations are associated with left ventricular hypertrophy, congestive heart failure, atrial fibrillation, and mortality. Increased extracellular phosphate directly affects endothelial cells causing cell apoptosis and vascular smooth muscle cells (VSMCs) causing transformation to osteogenic phenotype. Excess of calcium and phosphate in the circulation can promote the formation of protein-mineral complex called calciprotein particles (CPPs). In CKD, these CPPs contain less calcification inhibitors, induce inflammation, and promote VSMC calcification.
\end{abstract}

\section{Introduction}

The discovery of phosphorus occurred by accident in 1669 when a German alchemist named Hennig Brand boiled down 60 buckets of urine in search of the "philosopher's stone," a compound that would turn ordinary metals into gold. The discovered compound glowed in the dark in palegreen color, self-ignited and blew up into flame. He named the compound "phosphorus," which was taken from the Greek word meaning "bearer of light" [1]. Due to the high reactivity, phosphorus is never found as free element. White phosphorus has been used in manufacturing bombs and red phosphorus is used to make the strike plate of match boxes. The common use of phosphorus in the form of phosphoric acid nowadays is in the fertilizer industry.

Phosphorus is essential for life and exists in the body as phosphate. Phosphates are components of RNA, DNA, adenosine triphosphate (ATP), cell membrane, and bone. An average adult contains approximately 700 gram of phosphorus which is the result of an intake and excretion of 1-2 grams per day. Phosphate is excreted mostly in the urine. Only $0.1 \%$ of body phosphate circulates in the blood.

Despite its importance, the accumulation of phosphate can produce deleterious effects. Such example can be seen in end-stage renal disease patients when widespread vascular and soft tissue calcifications occur as a result of chronic phosphate accumulation. In early stages of chronic kidney disease (CKD), serum phosphate is normally maintained within the normal range owing to the compensatory increase in fibroblast growth factor-23 (FGF-23) and parathyroid hormone up until the estimated glomerular filtration rate (eGFR) reaching $30 \mathrm{~mL} / \mathrm{min} / 1.73 \mathrm{~m}^{2}$. Beyond this point hyperphosphatemia begins to develop [2, 3] (Figure 1). However, the accumulation of phosphate occurs long before the rise in serum phosphate above the upper normal limit since several observational studies in both general population and early-stage CKD patients have identified the relationship between high-normal serum phosphate and adverse cardiovascular outcomes. The following review will focus on the role of phosphate accumulation in 


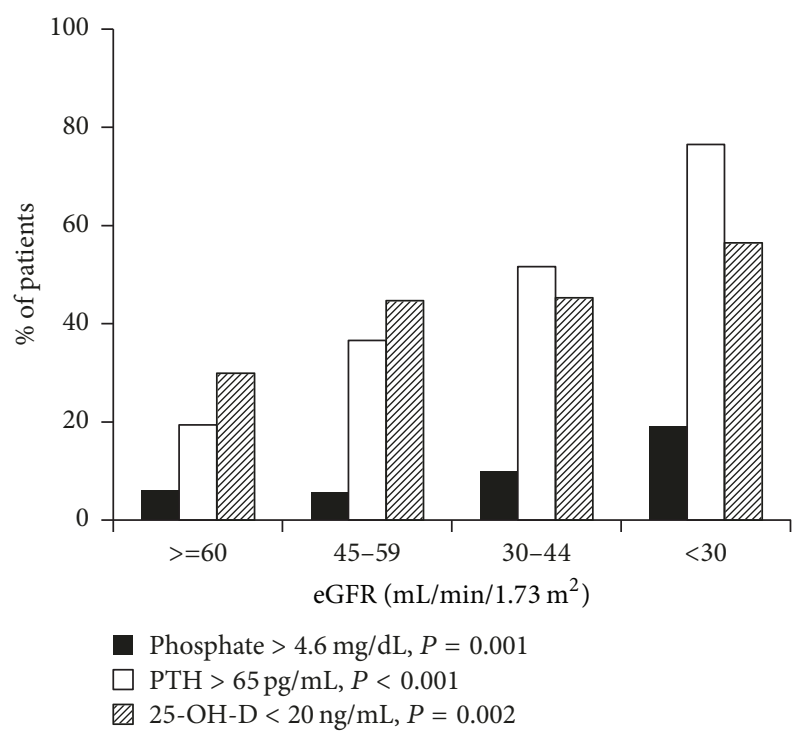

FIGURE 1: Prevalence of hyperphosphatemia according to kidney function. $P$ values represent the significance of trend. Reuse with permission from Chartsrisak et al. [3].

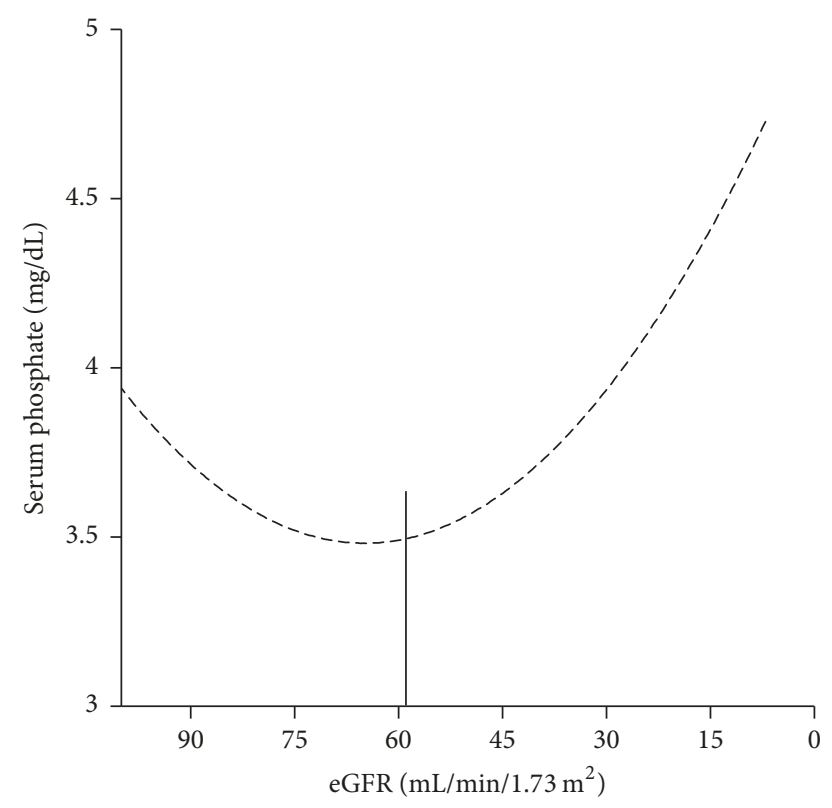

FIGURE 2: Serum phosphate according to kidney function. Vertical line represents the change in slope. Modified from Chartsrisak et al. [3].

cardiovascular disease (CVD) beyond CKD and vascular calcification.

\section{Serum Phosphate and Outcomes}

In $\mathrm{CKD}$, the gradual increase in serum phosphate can be observed since the beginning of stage 3 [2] (Figure 2). Several studies in early-stage CKD patients have identified the relationship between increased serum phosphate but still within the normal range with adverse cardiovascular and renal outcomes and overall survival [5-8]. The reported thresholds of serum phosphate in nondialysis CKD stages $2-5$ patients that have been shown to predict adverse outcomes ranged between 3.5 and $4.6 \mathrm{mg} / \mathrm{dL}$ (Table 1). These data suggest that phosphate accumulation occurs since early stages of CKD prior to the development of hyperphosphatemia. More interestingly, the relationship between high-normal serum phosphate and adverse outcomes extends beyond CKD population. Among population with preserved renal function (normally defined as eGFR $>=60 \mathrm{~mL} / \mathrm{min} / 1.73 \mathrm{~m}^{2}$ ), the increase in serum phosphate not only displays a relationship with makers of atherosclerosis, for example, vascular and valvular calcifications, but also predicts atherosclerotic and nonatherosclerotic cardiovascular events and mortality [919]. The reported thresholds of serum phosphate for adverse outcomes were lower than CKD population and ranged between 2.5 and $3.8 \mathrm{mg} / \mathrm{dL}$ (Table 1). Since two major factors that determine serum phosphate level are dietary phosphate and urinary excretion, it is likely that high dietary phosphate is one of the mediators of such relationship.

\section{Dietary Phosphate}

The study that included both healthy and CKD subjects revealed a circadian rhythm of serum phosphate after ingestion of phosphate-rich meal (Figure 3) [4]. Serum phosphate is lowest in the morning and highest at $4 \mathrm{pm}$ and midnight. Consumption of $1500 \mathrm{mg} /$ day (normal phosphate diet) and especially $2500 \mathrm{mg} /$ day of phosphate (high phosphate diet) resulted in a higher fasting and peak serum phosphate compared to consumption of $1000 \mathrm{mg}$ /day of phosphate plus lanthanum carbonate (low phosphate diet). This circadian rhythm also presents in CKD patients but is much less pronounced. Another study in both healthy humans and rats with varying degree of kidney function revealed similar findings. A more rapid elevation of serum phosphate was observed in humans and rats with higher levels of kidney function [20]. These data confirmed that high phosphate diet results in a substantial increase in both fasting and postprandial serum phosphate. Therefore, a habitual intake of high dietary phosphate is likely to chronically elevate serum phosphate, eventually resulting in unfavorable outcomes mentioned above. The study that examined a relationship between increased serum and dietary phosphate with biochemical markers of aging revealed significant associations with telomere length, DNA methylation content, and chronological age [21]. In this study, dietary derived phosphate was closely related to the amount of red meat consumption. Moreover, the relationship between serum phosphate (within the normal range) and dietary phosphate with left ventricular mass was observed in early stages of CKD patients as well as in individuals with preserved renal function $[22,23]$. In a large cohort of healthy subjects with no known CVD, dietary phosphate intake $>1$ gram/day was significantly associated with greater left ventricular mass after adjustment for confounders. Acute dietary phosphate load in healthy adult subjects can impair endothelial-dependent flow-mediated dilatation which may predispose to future atherosclerotic CVD $[24,25]$. The associations between increased serum 
TABLE 1: Thresholds of serum phosphate for cardiovascular events and mortality in early-stage CKD and general populations.

\begin{tabular}{|c|c|c|c|c|}
\hline Studies (year) & Populations & Number & $\begin{array}{c}\text { Serum phosphate } \\
(\mathrm{mg} / \mathrm{dL})\end{array}$ & Outcomes \\
\hline Kestenbaum et al. (2005) & $\begin{array}{c}\text { Women: } \mathrm{Cr} \geq 1.2 \mathrm{mg} / \mathrm{dL} \\
\text { Men: } \mathrm{Cr} \geq 1.5 \mathrm{mg} / \mathrm{dL}\end{array}$ & 3490 & $>=3.5$ & All-cause mortality \\
\hline Bellasi et al. (2011) & CKD stages $3-5$ & 1716 & $>=4.3$ & $\begin{array}{l}\text { Combined ESRD and } \\
\text { all-cause mortality }\end{array}$ \\
\hline Chartsrisak et al. (2013) & CKD stages $2-4$ & 466 & $>4.2$ & $\begin{array}{l}\text { Combined ESRD and } \\
\text { all-cause mortality }\end{array}$ \\
\hline McGovern et al. (2013) & CKD stages $3-5$ & 13292 & $>=4.6$ & $\begin{array}{l}\text { Combined CV events } \\
\text { and all-cause mortality }\end{array}$ \\
\hline McGovern et al. (2013) & CKD stages 1-2 & 20356 & $>=3.86$ & $\begin{array}{l}\text { Combined CV events } \\
\text { and all-cause mortality }\end{array}$ \\
\hline McGovern et al. (2013) & $\begin{array}{l}\text { eGFR }>=90, \text { no } \\
\text { proteinuria }\end{array}$ & 24184 & $>=3.86$ & $\begin{array}{l}\text { Combined CV events } \\
\text { and all-cause mortality }\end{array}$ \\
\hline \multirow{2}{*}{ Tonelli et al. (2005) } & \multirow{2}{*}{$\begin{array}{l}\text { Previous acute MI, eGFR } \\
\quad>=60 \mathrm{~mL} / \mathrm{min}\end{array}$} & \multirow{2}{*}{4127} & $>=2.5$ & All-cause mortality \\
\hline & & & $>=2.5$ & $\begin{array}{l}\text { Combined fatal and } \\
\text { non-fatal CV events }\end{array}$ \\
\hline Dhingra et al. (2007) & $\mathrm{eGFR}>=60 \mathrm{~mL} / \mathrm{min}$ & 3676 & $>=3.2$ & Incident CVD \\
\hline Foley et al. (2008) & $\begin{array}{c}97 \% \text { has eGFR }>= \\
60 \mathrm{~mL} / \mathrm{min}\end{array}$ & 13822 & $>=3.8$ & All-cause mortality \\
\hline Larsson et al. (2010) & $\begin{array}{c}\text { Men, eGFR > } \\
60 \mathrm{~mL} / \mathrm{min}\end{array}$ & 2176 & $>=2.8$ & All-cause mortality \\
\hline \multirow{2}{*}{ Chang and Grams (2014) } & \multirow{2}{*}{$\begin{array}{l}95 \% \text { has eGFR }>= \\
\quad 60 \mathrm{~mL} / \mathrm{min}\end{array}$} & \multirow{2}{*}{12984} & $>3.5$ & All-cause mortality \\
\hline & & & $>3.5$ & CV mortality \\
\hline
\end{tabular}

$\mathrm{CKD}=$ chronic kidney disease; $\mathrm{ESRD}=$ end-stage renal disease; $\mathrm{CV}=$ cardiovascular; $\mathrm{CVD}=$ cardiovascular disease; eGFR = estimated glomerular filtration rate; $\mathrm{MI}=$ myocardial infarction.

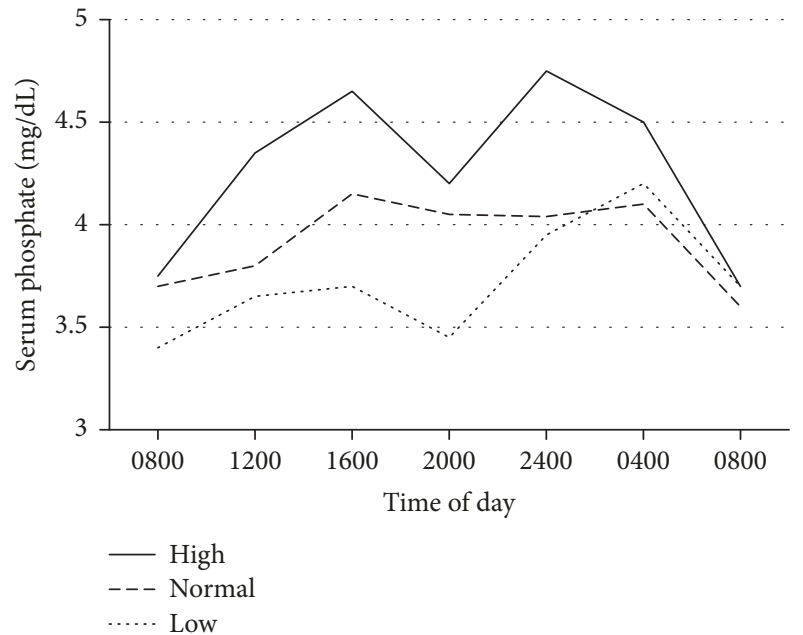

(a)

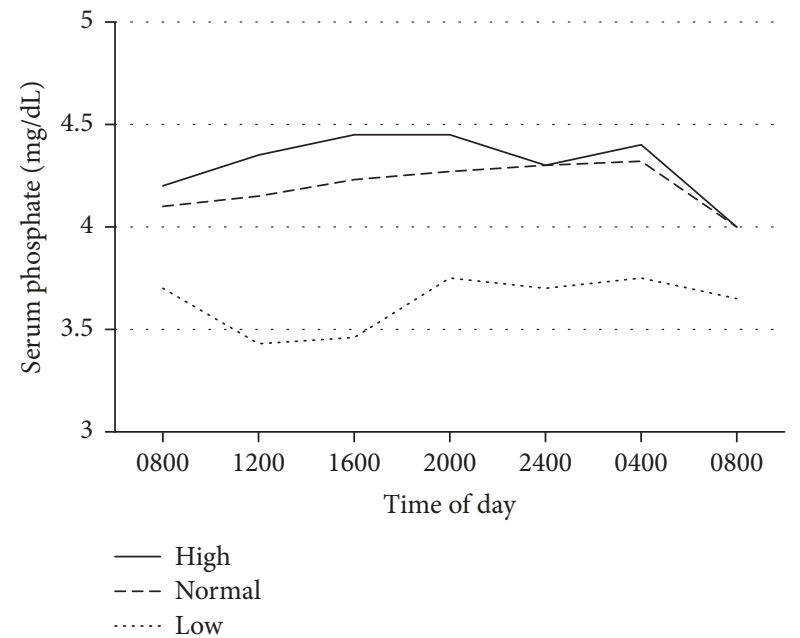

(b)

FIGURE 3: Serum phosphate concentrations throughout the day in healthy controls (a) and CKD patients (b). High phosphate = 2500 mg/day; normal phosphate $=1500 \mathrm{mg} /$ day; low phosphate $=1000 \mathrm{mg} /$ day plus lanthanum carbonate. Adapted from Ix et al. [4]. Reuse under the copyright license of free access article from American Society of Nutrition. https://nutrition.org/publications/guidelines-and-policies/license/.

phosphate and increased consumption of dietary phosphate additives with carotid intima-media thickness also exist [26, 27] In addition, dietary phosphate load can also increase FGF-23 concentration and the increase in FGF-23 has been linked to cardiac hypertrophy and adverse cardiovascular outcomes [28-30].

\section{Fibroblast Growth Factor-23}

FGF-23 is produced by osteoblasts and osteocytes in the bone under physiological condition. In the kidney, FGF-23 binds to FGF receptor in the proximal tubule in the presence of coreceptor klotho resulting an inhibition of proximal tubular 
phosphate reabsorption and a suppression of 1,25-dihydroxy vitamin D synthesis [31]. In CKD, FGF-23 levels increase since stage 2 and continue to rise as CKD progresses. In CKD stages 5-5D, FGF-23 levels are normally several hundred folds above the normal range $[2,32]$. In healthy subjects, FGF23 increases after hours of dietary phosphate load; however, a 4-hour intravenous infusion of phosphate does not alter FGF-23 level at 6 hours, whereas chronic phosphate infusion results in an increase in FGF-23 at 24 hours [28-30, 33, 34]. These data suggest a rather indirect influence of phosphate on FGF-23 secretion. The situation may be somewhat different in CKD when these patients are predisposed to phosphate accumulation due to reduced renal function. To date, the exact relationship between phosphate and FGF-23 in CKD remains unclear. In epidemiological studies, both eGFR and serum phosphate correlate closely with FGF-23 levels [35, 36]. Similar to healthy subjects, dietary phosphate load in subjects with impaired renal function results in an increase in circulating FGF-23 [37]. However, both experimental and epidemiological studies have confirmed the increase in circulating FGF-23 since CKD stage 2 prior to any significant accumulation of phosphate. This early increase in FGF-23 drives a dip in serum phosphate from baseline as a result of heightened urinary phosphate excretion (Figure 2) [2, 38]. These evidences indicate that, initially, the stimuli for FGF-23 secretion is the decline in eGFR followed by the accumulation of phosphate in the later period.

Several studies in populations with preserved renal function and early CKD have linked FGF-23 to left ventricular hypertrophy and decreased left ventricular ejection fraction [39-42]. Increased circulating FGF-23 has also been shown to predict incident and worsening heart failure, atrial fibrillation, cardiovascular events, and mortality [40, 43-55]. One of the important evidences that connects high circulating FGF-23 to abnormal cardiac structure and function is the direct effect of FGF-23 on cardiomyocytes. Pathological level of FGF-23 can induce cardiomyocyte hypertrophy through its binding to FGF receptor- 4 in a klotho-independent manner $[56,57]$. Further evidence also indicates that the stressed myocardium under pressure or volume overload can also produce FGF-23 resulting in a marked increase in FGF-23 level [58]. These data suggest that the stimuli for FGF-23 secretion include not only diminished renal function and phosphate load but also myocardium under stress. The latter explains the rather consistent relationship between increased FGF-23 levels with cardiac hypertrophy and heart failure in the population with preserved renal function. Furthermore, the antagonistic effect of FGF-23 on 1,25-dihydroxyvitamin D can also trigger renin-angiotensin-aldosterone system resulting in an increase in sodium reabsorption [54, 59]. Recent evidence also suggests that FGF-23 is a negative regulator of erythropoiesis and may promote inflammation [60-62].

\section{Extracellular Phosphate and Cytotoxicity}

Increased extracellular phosphate can induce vascular smooth muscle cell (VSMC) transformation to osteogenic phenotype [63]. These osteogenic VSMCs can release matrix vesicles in a similar fashion to osteoblasts but with less calcification inhibitor, matrix-gla protein. Dying VSMCs also form apoptotic body. Both matrix vesicles and apoptotic bodies have the ability to concentrate and crystalize calcium and phosphate in the preparation for mineralization [64]. In addition to the effect on VSMCs, increased extracellular phosphate can also induce endothelial cell apoptosis [65]. Recent knowledge on extracellular phosphate and cytotoxicity is derived from works related to the formation of protein-mineral complex or calciprotein particles (CPPs). First, fetuin-A, a naturally occurring calcification inhibitor, binds and sequesters calcium and phosphate forming primary CPPs. Primary CPPs then undergo topological rearrangement to form a more stable structure referred to as secondary CPPs. These CPPs exist as colloids and do not precipitate spontaneously [66]. Serum CPP levels increase as kidney function declines and correlate independently with serum phosphate. CPPs can be detected since early stages of CKD when baseline serum phosphate is still within the normal range $[67,68]$. At first, CPPs were believed to play a protective role in sequestering and inhibiting calcium-phosphate crystal growth. However, several observational studies have identified the relationship between increased circulating CPPs, especially secondary CPPs, with inflammation, coronary artery calcification, aortic stiffness, and mortality $[68,69]$. It is possible that CPPs are bioactive ligand that can induce cellular toxicity. Indeed, in vitro studies have shown that secondary CPPs (not primary CPPs) can induce inflammation and promote osteogenic differentiation of VSMCs [70, 71]. The recent study has also identified the difference between CPPs from healthy subjects and CPPs from CKD patients. Secondary CPPs from CKD patients have lower levels of calcification inhibitors, fetuin-A, and Gla-rich protein, with increased mineral maturation. These secondary CPPs are readily taken up by VSMCs and induce vascular calcification [72].

In conclusion, phosphate accumulation produces detrimental effects on cardiovascular system resulting in poor patient outcomes. The accumulation of phosphate occurs long before the rise in serum phosphate above the normal range. High phosphate diet can increase serum phosphate and FGF-23. FGF-23 has a direct effect on cardiac myocytes causing myocardial hypertrophy. Increased extracellular phosphate is toxic to endothelial cells, promotes the formation of CPPs, and induces VSMC transformation to osteogenic phenotype.

\section{Conflicts of Interest}

Sinee Disthabanchong has served as an advisory board member of Sanofi and accepted honorarium and travel grants from Sanofi, Fresenius Kabi, and Kyowa Hakko Kirin.

\section{References}

[1] M. E. Weeks, "The discovery of the elements.II. elements known to the alchemists," Journal of Chemical Education, vol. 9, no. I, pp. 11-21, 1932.

[2] T. Isakova, P. Wahl, G. S. Vargas et al., "Fibroblast growth factor 23 is elevated before parathyroid hormone and phosphate in 
chronic kidney disease," Kidney International, vol. 79, no. 12, pp. 1370-1378, 2011.

[3] K. Chartsrisak, K. Vipattawat, M. Assanatham et al., "Mineral metabolism and outcomes in chronic kidney disease stage 2-4 patients," BMC Nephrology, vol. 14, no. 1, article no. 14, 2013.

[4] J. H. Ix, C. A. M. Anderson, G. Smits, M. S. Persky, and G. A. Block, "Effect of dietary phosphate intake on the circadian rhythm of serum phosphate concentrations in chronic kidney disease: A crossover study," American Journal of Clinical Nutrition, vol. 100, no. 5, pp. 1392-1397, 2014.

[5] B. Kestenbaum, J. N. Sampson, K. D. Rudser et al., "Serum phosphate levels and mortality risk among people with chronic kidney disease," Journal of the American Society of Nephrology, vol. 16, no. 2, pp. 520-528, 2005.

[6] A. Bellasi, M. Mandreoli, L. Baldrati et al., "Chronic kidney disease progression and outcome according to serum phosphorus in mild-to-moderate kidney dysfunction," Clinical Journal of the American Society of Nephrology, vol. 6, no. 4, pp. 883-891, 2011.

[7] A. P. McGovern, S. de Lusignan, J. van Vlymen et al., "Serum Phosphate as a Risk Factor for Cardiovascular Events in People with and without Chronic Kidney Disease: A Large Community Based Cohort Study," PLoS ONE, vol. 8, no. 9, Article ID e74996, 2013.

[8] J. Da, X. Xie, M. Wolf et al., "Serum Phosphorus and Progression of CKD and Mortality: A Meta-analysis of Cohort Studies," American Journal of Kidney Diseases, vol. 66, no. 2, pp. 258-265, 2015.

[9] M. Tonelli, F. Sacks, M. Pfeffer, Z. Gao, and G. Curhan, "Relation between serum phosphate level and cardiovascular event rate in people with coronary disease," Circulation, vol. 112, no. 17, pp. 2627-2633, 2005.

[10] R. Dhingra, L. M. Sullivan, C. S. Fox et al., "Relations of serum phosphorus and calcium levels to the incidence of cardiovascular disease in the community," JAMA Internal Medicine, vol. 167, no. 9, pp. 879-885, 2007.

[11] R. N. Foley, A. J. Collins, A. Ishani, and P. A. Kalra, "Calciumphosphate levels and cardiovascular disease in communitydwelling adults: The Atherosclerosis Risk in Communities (ARIC) Study," American Heart Journal, vol. 156, no. 3, pp. 556$563,2008$.

[12] R. N. Foley, "Phosphate levels and cardiovascular disease in the general population," Clinical Journal of the American Society of Nephrology, vol. 4, no. 6, pp. 1136-1139, 2009.

[13] T. E. Larsson, H. Olauson, E. Hagström et al., "Conjoint effects of serum calcium and phosphate on risk of total, cardiovascular, and noncardiovascular mortality in the community," Arteriosclerosis, Thrombosis, and Vascular Biology, vol. 30, no. 2, pp. 333-339, 2010.

[14] J. P. Linefsky, K. D. OBrien, R. Katz et al., "Association of serum phosphate levels with aortic valve sclerosis and annular calcification," Journal of the American College of Cardiology, vol. 58, no. 3, pp. 291-297, 2011.

[15] S. Shin, K.-J. Kim, H.-J. Chang et al., "Impact of serum calcium and phosphate on coronary atherosclerosis detected by cardiac computed tomography," European Heart Journal, vol. 33, no. 22, pp. 2873-2881, 2012.

[16] S. G. Wannamethee, N. Sattar, O. Papcosta, L. Lennon, and P. H. Whincup, "Alkaline phosphatase, serum phosphate, and incident cardiovascular disease and total mortality in older men," Arteriosclerosis, Thrombosis, and Vascular Biology, vol. 33, no. 5, pp. 1070-1076, 2013.
[17] A. R. Chang and M. E. Grams, "Serum Phosphorus and mortality in the Third National Health and Nutrition Examination Survey (NHANES III): Effect modification by fasting," American Journal of Kidney Diseases, vol. 64, no. 4, pp. 567-573, 2014.

[18] J.-W. Li, C. Xu, Y. Fan, Y. Wang, and Y.-B. Xiao, "Can serum levels of alkaline phosphatase and phosphate predict cardiovascular diseases and total mortality in individuals with preserved renal function? A systemic review and meta-analysis," PLoS ONE, vol. 9, no. 7, Article ID e102276, 2014.

[19] W. Bai, J. Li, and J. Liu, "Serum phosphorus, cardiovascular and all-cause mortality in the general population: A meta-analysis," Clinica Chimica Acta, vol. 461, pp. 76-82, 2016.

[20] M. E. Turner, C. A. White, W. M. Hopman et al., "Impaired Phosphate Tolerance Revealed With an Acute Oral Challenge," Journal of Bone and Mineral Research, vol. 33, no. 1, pp. 113-122, 2018.

[21] R. McClelland, K. Christensen, S. Mohammed et al., "Accelerated ageing and renal dysfunction links lower socioeconomic status and dietary phosphate intake," $A G I N G$, vol. 8, no. 5, pp. 1135-1149, 2016.

[22] C. D. Chue, N. C. Edwards, W. E. Moody, R. P. Steeds, J. N. Townend, and C. J. Ferro, "Serum phosphate is associated with left ventricular mass in patients with chronic kidney disease: A cardiac magnetic resonance study," Heart, vol. 98, no. 3, pp. 219224, 2012.

[23] K. T. Yamamoto, C. Robinson-Cohen, M. C. De Oliveira et al., "Dietary phosphorus is associated with greater left ventricular mass," Kidney International, vol. 83, no. 4, pp. 707-714, 2013.

[24] E. Shuto, Y. Taketani, R. Tanaka et al., "Dietary phosphorus acutely impairs endothelial function," Journal of the American Society of Nephrology, vol. 20, no. 7, pp. 1504-1512, 2009.

[25] B. M. Levac, M. A. Adams, and K. E. Pyke, "The impact of an acute oral phosphate load on endothelium dependent and independent brachial artery vasodilation in healthy males," Applied Physiology, Nutrition, and Metabolism, vol. 42, no. 12, pp. 1307-1315, 2017.

[26] S. T. Itkonen, H. J. Karp, V. E. Kemi et al., "Associations among total and food additive phosphorus intake and carotid intimamedia thickness - A cross-sectional study in a middle-aged population in Southern Finland," Nutrition Journal , vol. 12, no. 1, article no. 94, 2013.

[27] A. Ramírez-Morros, M. Granado-Casas, N. Alcubierre et al., "Calcium Phosphate Product Is Associated with Subclinical Carotid Atherosclerosis in Type 2 Diabetes," Journal of Diabetes Research, vol. 2017, pp. 1-8, 2017.

[28] S. L. Ferrari, J.-P. Bonjour, and R. Rizzoli, "Fibroblast growth factor-23 relationship to dietary phosphate and renal phosphate handling in healthy young men," The Journal of Clinical Endocrinology \& Metabolism, vol. 90, no. 3, pp. 1519-1524, 2005.

[29] Y. Nishida, Y. Taketani, H. Yamanaka-Okumura et al., "Acute effect of oral phosphate loading on serum fibroblast growth factor 23 levels in healthy men," Kidney International, vol. 70, no. 12, pp. 2141-2147, 2006.

[30] S.-A. M. Burnett, S. C. Gunawardene, F. R. Bringhurst, H. Jüppner, H. Lee, and J. S. Finkelstein, "Regulation of C-terminal and intact FGF-23 by dietary phosphate in men and women," Journal of Bone and Mineral Research, vol. 21, no. 8, pp. 11871196, 2006.

[31] T. Shimada, H. Hasegawa, Y. Yamazaki et al., "FGF-23 is a potent regulator of vitamin $\mathrm{D}$ metabolism and phosphate 
homeostasis," Journal of Bone and Mineral Research, vol. 19, no. 3, pp. 429-435, 2004.

[32] R. C. Pereira, H. Juppner, C. E. Azucena-Serrano, O. Yadin, I. B. Salusky, and K. Wesseling-Perry, "Patterns of FGF-23, DMP1, and MEPE expression in patients with chronic kidney disease," Bone, vol. 45, no. 6, pp. 1161-1168, 2009.

[33] N. Ito, S. Fukumoto, Y. Takeuchi et al., "Effect of acute changes of serum phosphate on fibroblast growth factor (FGF) 23 levels in humans," Journal of Bone and Mineral Metabolism, vol. 25, no. 6, pp. 419-422, 2007.

[34] N. Arai-Nunota, M. Mizobuchi, H. Ogata et al., "Intravenous phosphate loading increases fibroblast growth factor 23 in uremic rats," PLoS ONE, vol. 9, no. 3, Article ID e91096, 2014.

[35] O. Gutierrez, T. Isakova, E. Rhee et al., "Fibroblast growth factor-23 mitigates hyperphosphatemia but accentuates calcitriol deficiency in chronic kidney disease," Journal of the American Society of Nephrology, vol. 16, no. 7, pp. 2205-2215, 2005.

[36] D. Fliser, B. Kollerits, U. Neyer et al., "Fibroblast growth factor 23 (FGF23) predicts progression of chronic kidney disease: the Mild to Moderate Kidney Disease (MMKD) Study," Journal of the American Society of Nephrology, vol. 18, no. 9, pp. 2600-2608, 2007.

[37] M. Sigrist, M. Tang, M. Beaulieu et al., "Responsiveness of FGF23 and mineral metabolism to altered dietary phosphate intake in chronic kidney disease (CKD): Results of a randomized trial," Nephrology Dialysis Transplantation, vol. 28, no. 1, pp. 161-169, 2013.

[38] H. Hasegawa, N. Nagano, I. Urakawa et al., "Direct evidence for a causative role of FGF23 in the abnormal renal phosphate handling and vitamin $\mathrm{D}$ metabolism in rats with early-stage chronic kidney disease," Kidney International, vol. 78, no. 10, pp. 975-980, 2010.

[39] O. M. Gutiérrez, J. L. Januzzi, T. Isakova et al., "Fibroblast growth factor 23 and left ventricular hypertrophy in chronic kidney disease," Circulation, vol. 119, no. 19, pp. 2545-2552, 2009.

[40] S. Seiler, B. Cremers, N. M. Rebling et al., "The phosphatonin fibroblast growth factor 23 links calciumphosphate metabolism with left-ventricular dysfunction and atrial fibrillation," European Heart Journal, vol. 32, no. 21, pp. 2688-2696, 2011.

[41] K. Smith, C. Defilippi, T. Isakova et al., "Fibroblast growth factor 23, high-sensitivity cardiac troponin, and left ventricular hypertrophy in CKD," American Journal of Kidney Diseases, vol. 61, no. 1, pp. 67-73, 2013.

[42] I. Agarwal, N. Ide, J. H. Ix et al., "Fibroblast growth factor-23 and cardiac structure and function," Journal of the American Heart Association, vol. 3, no. 1, Article ID e000584, 2014.

[43] S. Seiler, B. Reichart, D. Roth, E. Seibert, D. Fliser, and G. H. Heine, "FGF-23 and future cardiovascular events in patients with chronic kidney disease before initiation of dialysis treatment," Nephrology Dialysis Transplantation, vol. 25, no. 12, pp. 3983-3989, 2010.

[44] J. Kendrick, A. K. Cheung, J. S. Kaufman et al., "FGF-23 associates with death, cardiovascular events, and initiation of chronic dialysis," Journal of the American Society of Nephrology, vol. 22, no. 10, pp. 1913-1922, 2011.

[45] J. H. Ix, R. Katz, B. R. Kestenbaum et al., "Fibroblast growth factor-23 and death, heart failure, and cardiovascular events in community-living individuals: CHS (Cardiovascular Health Study)," Journal of the American College of Cardiology, vol. 60, no. 3, pp. 200-207, 2012.
[46] J. S. Mathew, M. C. Sachs, and R. Katz, "Fibroblast growth factor-23 and incident atrial fibrillation: The multi-ethnic study of atherosclerosis (MESA) and the cardiovascular health study (CHS)," Circulation, vol. 130, no. 4, pp. 298-307, 2014.

[47] B. Kestenbaum, M. C. Sachs, A. N. Hoofnagle et al., "Fibroblast growth factor-23 and cardiovascular disease in the general population the multi-ethnic study of atherosclerosis," Circulation: Heart Failure, vol. 7, no. 3, pp. 409-417, 2014.

[48] J. J. Scialla, H. Xie, M. Rahman et al., "Fibroblast growth factor23 and cardiovascular events in CKD," Journal of the American Society of Nephrology, vol. 25, no. 2, pp. 349-360, 2014.

[49] J. A. Udell, D. A. Morrow, P. Jarolim et al., "Fibroblast growth factor-23, cardiovascular prognosis, and benefit of angiotensinconverting enzyme inhibition in stable ischemic heart disease," Journal of the American College of Cardiology, vol. 63, no. 22, pp. 2421-2428, 2014.

[50] S. Seiler, K. S. Rogacev, H. J. Roth et al., "Associations of FGF23 and sKlotho with cardiovascular outcomes among patients with CKD stages 2-4," Clinical Journal of the American Society of Nephrology, vol. 9, no. 6, pp. 1049-1058, 2014.

[51] R. D. Giuseppe, B. Buijsse, F. Hirche et al., "Plasma fibroblast growth factor 23, parathyroid hormone, 25-hydroxyvitamin D3, and risk of heart failure: A prospective, case-cohort study," The Journal of Clinical Endocrinology \& Metabolism, vol. 99, no. 3, pp. 947-955, 2014.

[52] L. Koller, M. E. Kleber, V. M. Brandenburg et al., "Fibroblast Growth Factor 23 Is an Independent and Specific Predictor of Mortality in Patients With Heart Failure and Reduced Ejection Fraction," Circulation: Heart Failure, vol. 8, no. 6, pp. 1059-1067, 2015.

[53] P. L. Lutsey, A. Alonso, E. Selvin et al., "Fibroblast growth factor23 and incident coronary heart disease, heart failure, and cardiovascular mortality: The atherosclerosis risk in communities study," Journal of the American Heart Association, vol. 3, no. 3, Article ID 000936, 2014.

[54] P. Wohlfahrt, V. Melenovsky, M. Kotrc et al., "Association of Fibroblast Growth Factor-23 Levels and AngiotensinConverting Enzyme Inhibition in Chronic Systolic Heart Failure," JACC: Heart Failure, vol. 3, no. 10, article no. 349, pp. 829839, 2015.

[55] J. M. ter Maaten, A. A. Voors, K. Damman et al., "Fibroblast growth factor 23 is related to profiles indicating volume overload, poor therapy optimization and prognosis in patients with new-onset and worsening heart failure," International Journal of Cardiology, vol. 253, pp. 84-90, 2018.

[56] C. Faul, A. P. Amaral, B. Oskouei et al., "FGF23 induces left ventricular hypertrophy," The Journal of Clinical Investigation, vol. 121, no. 11, pp. 4393-4408, 2011.

[57] A. Grabner, A. P. Amaral, K. Schramm et al., "Activation of Cardiac Fibroblast Growth Factor Receptor 4 Causes Left Ventricular Hypertrophy," Cell Metabolism, vol. 22, no. 6, pp. 1020-1032, 2015.

[58] S. Slavic, K. Ford, M. Modert et al., "Genetic Ablation of Fgf23 or Klotho Does not Modulate Experimental Heart Hypertrophy Induced by Pressure Overload," Scientific Reports, vol. 7, no. 1, Article ID 11298, 2017.

[59] M. H. de Borst, M. G. Vervloet, P. M. ter Wee, and G. Navis, "Cross talk between the renin-angiotensin-aldosterone system and vitamin D-FGF-23-klotho in chronic kidney disease," Journal of the American Society of Nephrology, vol. 22, no. 9, pp. 1603-1609, 2011. 
[60] L. M. Coe, S. V. Madathil, C. Casu, B. Lanske, S. Rivella, and D. Sitara, "FGF-23 is a negative regulator of prenatal and postnatal erythropoiesis," The Journal of Biological Chemistry, vol. 289, no. 14, pp. 9795-9810, 2014.

[61] M. Holecki, J. Chudek, A. Owczarek et al., "Inflammation but not obesity or insulin resistance is associated with increased plasma fibroblast growth factor 23 concentration in the elderly," Clinical Endocrinology, vol. 82, no. 6, pp. 900-909, 2015.

[62] S. Singh, A. Grabner, C. Yanucil et al., "Fibroblast growth factor 23 directly targets hepatocytes to promote inflammation in chronic kidney disease," Kidney International, vol. 90, no. 5, pp. 985-996, 2016.

[63] S. Jono, M. D. McKee, C. E. Murry et al., "Phosphate regulation of vascular smooth muscle cell calcification," Circulation Research, vol. 87, no. 7, pp. e10-e17, 2000.

[64] J. L. Reynolds, A. J. Joannides, J. N. Skepper et al., "Human vascular smooth muscle cells undergo vesicle-mediated calcification in response to changes in extracellular calcium and phosphate concentrations: a potential mechanism for accelerated vascular calcification in ESRD," Journal of the American Society of Nephrology, vol. 15, no. 11, pp. 2857-2867, 2004.

[65] G. S. Di Marco, M. Hausberg, U. Hillebrand et al., "Increased inorganic phosphate induces human endothelial cell apoptosis in vitro," American Journal of Physiology-Renal Physiology, vol. 294, no. 6, pp. F1381-F1387, 2008.

[66] M. Kuro-o, "Klotho, phosphate and FGF-23 in ageing and disturbed mineral metabolism," Nature Reviews Nephrology, vol. 9, no. 11, pp. 650-660, 2013.

[67] T. Hamano, I. Matsui, S. Mikami et al., "Fetuin-mineral complex reflects extraosseous calcification stress in CKD," Journal of the American Society of Nephrology, vol. 21, pp. 1998-2007, 2010.

[68] E. R. Smith, M. L. Ford, L. A. Tomlinson, C. Rajkumar, L. P. McMahon, and S. G. Holt, "Phosphorylated fetuin-A-containing calciprotein particles are associated with aortic stiffness and a procalcific milieu in patients with pre-dialysis CKD," Nephrology Dialysis Transplantation, vol. 27, no. 5, pp. 19571966, 2012.

[69] E. R. Smith, M. L. Ford, L. A. Tomlinson et al., "Serum calcification propensity predicts all-cause mortality in predialysis CKD," Journal of the American Society of Nephrology, vol. 25, no. 2, pp. 339-348, 2014.

[70] E. R. Smith, E. Hanssen, L. P. McMahon, and S. G. Holt, "FetuinA-containing calciprotein particles reduce mineral stress in the macrophage," PLoS ONE, vol. 8, no. 4, Article ID e60904, 2013.

[71] P. Aghagolzadeh, M. Bachtler, R. Bijarnia et al., "Calcification of vascular smooth muscle cells is induced by secondary calciprotein particles and enhanced by tumor necrosis factora," Atherosclerosis, vol. 251, pp. 404-414, 2016.

[72] C. S. Viegas, L. Santos, A. L. Macedo et al., "Chronic Kidney Disease Circulating Calciprotein Particles and Extracellular Vesicles Promote Vascular Calcification: A Role for GRP (GlaRich Protein)," Arteriosclerosis, Thrombosis, and Vascular Biology, vol. 38, no. 3, pp. 575-587, 2018. 


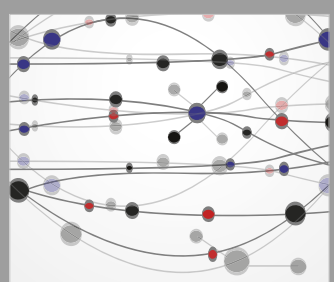

The Scientific World Journal
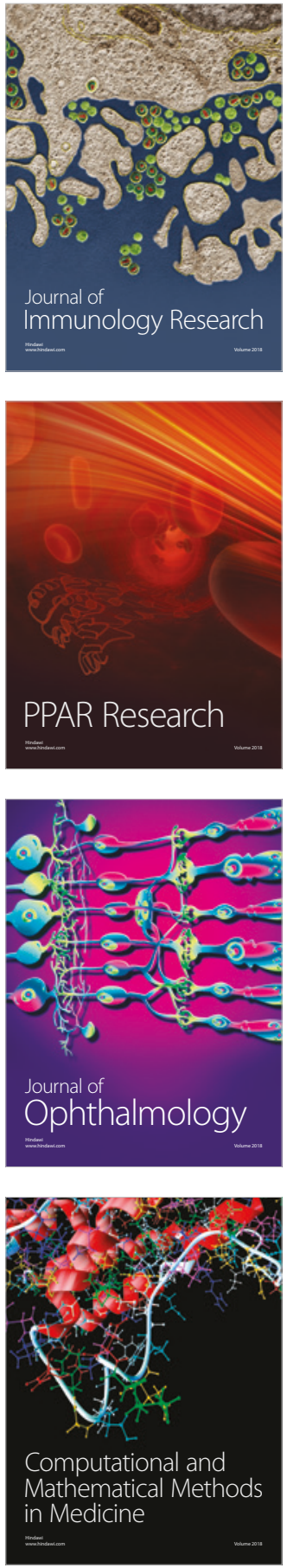

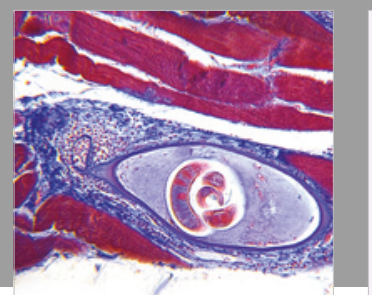

Gastroenterology Research and Practice

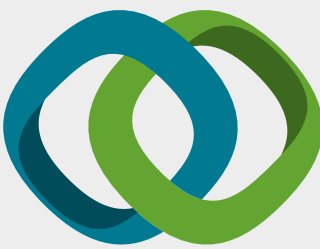

\section{Hindawi}

Submit your manuscripts at

www.hindawi.com
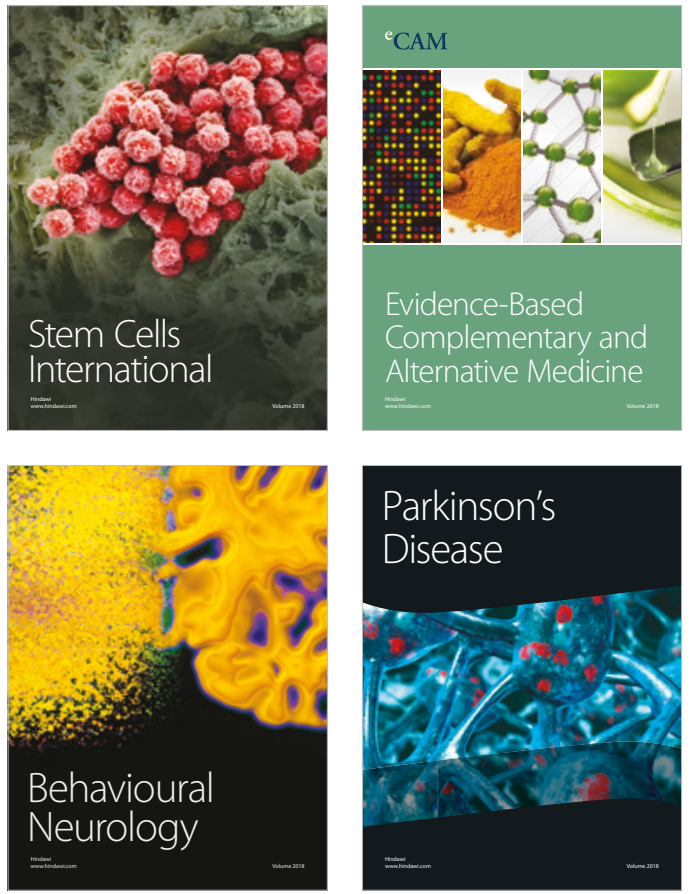

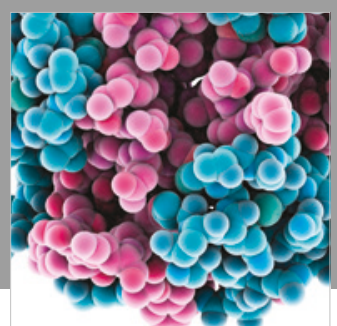

ournal of

Diabetes Research

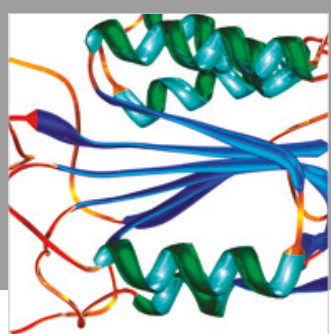

Disease Markers
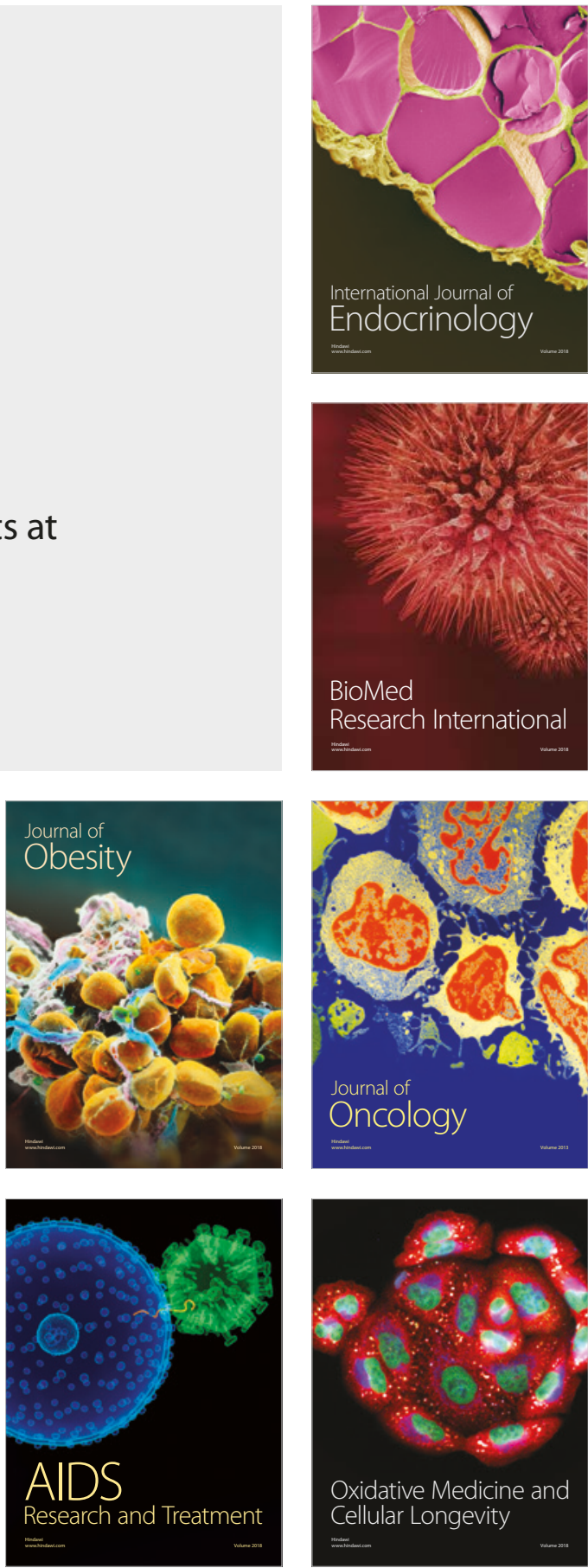